\title{
Optimal Asset Allocation of Pension Funds under a Value-at-Risk Constraint
}

\author{
Jiwon Chae, Ph.D Candidate, Pohang University of Science and Technology \\ Bong-Gyu Jang ${ }^{* *}$, Professor, Pohang University of Science and Technology
}

\begin{abstract}
$\langle$ Abstract〉
Pension funds must consider both liabilities and assets simultaneously from the perspective of Asset-Liability Management (ALM) to ensure financial soundness. In the context of such ALM schemes, this study presents an optimal portfolio strategy that maximizes the pension fund managers' utility score as measured by the funding ratio. Our model includes a Value-at-Risk (or shortfall) constraint at the end of the investment horizon. We extend the model in Kraft and Steffensen (2013) to a model with multiple risky assets. Our examples demonstrate that optimal fund managers with high risk-aversion should increase their investment proportions in risky assets when the funding ratio is slightly below the target value, but should first reduce their risky investment and maintain a certain level if the funding ratio is far away from the target value. In addition, as the correlation coefficient between risky assets decreases, the optimal risky proportions increase and their gap decreases. We can interpret this to mean that the stronger the negative correlation is, the stronger the hedging effect between the risky assets is.
\end{abstract}

Keywords: Asset Allocation; Pension Fund; Value-at-Risk; Funding Ratio; Liability-driven Investment

JEL Classification: G11, G23

\footnotetext{
* This work was supported by the Ministry of Education of the Republic of Korea and the National Research Foundation of Korea (NRF-2019S1A5A2A03054249)

** Corresponding Author. Address: Department of Industrial and Management Engineering, 77, Cheongam-ro, Nam-gu, Pohang-si, Gyeongsangbuk-do, Korea; 37673; E-mail: bonggyujang@postech.ac.kr; Tel: +82-54-279-3372; Fax: +82-54-279-2870.
}

Received: December 15, 2020; Revised: February 8, 2021; Accepted: February 15, 2021 


\title{
Value-at-Risk 제약 하에서의 연기금의 자산배분
}

\author{
채 지 원 (포항공과대학교 박사과정) \\ 장 봉 규 (포항공과대학교 교수) ${ }^{* *}$
}

\begin{abstract}
연기금은 재정건정성을 보장하기 위해 자산부채종합관리를 이용하여 부채와 자산을 동시에 고려할 필요가 있다. 본 연구에서는 이러한 자산부채종합관리의 개념을 반영하여 목적함수를 연기금의 적립비율로 설정하며, 투자기간의 마지막 시점에 Value-at-Risk 제약조건을 포함하는 최적 포트폴리오 전략을 제시하였다. 이를 위해 Kraft and Steffensen(2013)이 제안한 제약조건이 있을 때의 포트폴리오 문제 해결 방법론을 여러 개의 위험자산이 있는 모형으로 확장하였다. 몇 가지 예시에서 적절한 모수 선택과 수치적 실험을 통해, 위험회피성향이 강한 연기금의 펀드매니저는 펀드의 적립비율이 목표적립 비율 부근에서 조금씩 낮아질수록 위험자산의 투자비중을 높여야 하나, 충분히 낮아질 경우 투자비중을 줄인 다음 일정 수준을 유지해야 한다는 사실을 발견하였다. 또한, 투자대상이 되는 위험자산 간의 상관계수가 감소할수록 각 위험자산의 투자비중은 증가하며 위험자산 간의 투자비중 격차는 줄어드는 것을 확인하였다.
\end{abstract}

핵심 단어 : 자산배분, 연기금, Value-at-Risk, 적립비율, 부채연계투자

JEL 분류기호: G11, G23

* 이 논문은 2019년 정부의 재원으로 한국연구재단의 지원을 받아 수행된 연구입니다.

(NRF-2019S1A5A2A03054249).

** 연락담당 저자. 주소: 경북 포항시 남구 청암로 $77 \mathrm{POSTECH} \mathrm{산업경영공학과,} \mathrm{37673;}$

E-mail: bonggyujang@postech.ac.kr; Tel: 054-279-3372; Fax: 054-279-2870. 


\section{1. 서론}

흔히 우리는 연기금을 보험, 보증, 특정 사업 등을 위해 운용하는 기금으로 해석한다. 그 연기금에는 공제회, 조합 또는 개인 등의 보유 자산을 유동화하고자 하는 자산보유자들의 자산까지 포함되어 있다. 자산보유자들은 재정건정성을 중요시하는데, 이는 예측되거나 보유하고 있는 부채보다 자산이 항상 크도록 유지하는 것을 말하며, 이러한 방식으로 자산과 부채를 함께 고려하는 것이 자산부채종합관리이며, 보험사와 같이 엄격한 규제로 관리되는 곳에서 생긴 개념이다. 자산부채종합관리는 자산보유자의 전체 수익률을 높이는 데만 목표를 두는 것이 아니라 위험과 수익을 동시에 고려하기 때문에 현실적인 자산운용이 되게 할 가능성이 크다. 이를 반영하기 위해 일반적으로 사용되는 부의 최대화(wealth maximization) 문제가 아닌 부채의 증가율이 포함된 목적함수를 이용함으로써 자산부채종합관리를 문제화 할 수 있다.

고전적인 포트폴리오 최적화는 제약조건이 없는 최적의 포트폴리오 선택을 다루지만 실제로 부(wealth) 또는 적립비율(funding ratio)에 대한 제약이 필요하다. 예를 들어, 연기금은 미지급 또는 지연된 지급이 발생하지 않도록 추정된 지출을 기반으로 한 위험 조정 비율을 제어할 필요가 있다. 이때 흔히 사용하는 재정건정성 지표가 적립비율이다. 적립비율은 연기금의 입장에서 부채나 예상되는 지출에 대한 자산을 의미한다. 이때, 비율이 1 이상일 경우, 연기금은 부채를 상환할 능력이 가능하다고 판단되는 반면, 반대의 경우에는 연기금이 부채를 완전히 갚을 수 없는 위험에 있다고 여겨진다. 적립비율을 제어하는 것은 연기금이 재정건정성을 지속하는 데에 있어 큰 역할을 한다. 따라서 연기금의 적립비율을 극대화하는 것과 동시에 연기금이 지출이 필요한 시점에 최소한의 기준을 맞추는 것이 필요하다. 이를 위해 본 연구에서는 적립비율이 버퍼를 넘는 확률을 제약할 수 있는 위험 허용한도를 고려하여 연기금 포트폴리오를 구성한다.

본 연구는 포트폴리오 선택과 자산 가격 책정이라는 기업 금융, 특히 연기금에서 필수적인 두 가지 주요 주제를 통합한 최적의 포트폴리오 선택 모델을 제시한다. 본 연구에서 사용되는 모형 및 연구방법론은 다음의 두 가지 특징이 있다. 첫째, 동적 프로그래밍을 적용하는 $\mathrm{VaR}$ 제약 조건의 존재를 고려한다. 둘째, 잘 사용되는 부(wealth)의 최대화 문제 대신에 우리는 자산과 부채라는 두 가지 프로세스를 통합한 적립비율을 활용하며, 최적 포트폴리오 구성을 위해 Kraft and Steffensen(2013)의 방법론을 따른다. 본 연구에서는 이 두 가지 특징을 함께 다룸으로써 현실적으로 연기금의 자산배분 및 위험관리에 기여할 수 있을 것으로 생각한다.

한편, 연속시간에서의 포트폴리오 최적화 문제는 마팅게일 접근방식(martingale approach)과 동적 프로그래밍 접근방식(dynamic programing approach) 등으로 해결해 왔다. Karatzas et al.(1987)에 설명되어 있는 마팅게일 접근방식은 정적(static) 최적화 방법으로 포트폴리오 선택 문제를 해결할 수 있다는 이점이 있으나 본 문제에서는 적합하지 않았다. 본 연구에서는 동적 프로그래밍 접근방식을 활용하여 문제를 해결하였으며, 이 방법은 가치 함수(value function)을 직접적으로 얻기가 비교적 쉽다는 이점이 있다. 동적 프로그래밍 접근방식과 관련된 포트폴리오 선택 문제에 대해서는 수많은 참고문헌이 존재한다. 예를 들자면, Grossman and 
Optimal Asset Allocation of Pension Funds under a Value-at-Risk Constraint

Zhou(1996)는 투자 종료 시점에서의 부의 제약이 있을 경우의 최적 포트폴리오 문제를 연구하여 그 제약조건의 존재가 부의 수준(wealth level)과 포트폴리오 선택 모두에 영향을 줄 수 있다고 결론지었다. Basak and Shapiro(2001)은 VaR 제약조건과 Expected Shortfall 조건인 두 가지 유형의 제약조건이 있는 포토폴리오 선택 문제를 다맀다. 그들은 $\mathrm{VaR}$ 만 고려하는 것은 위험 자산에 막대한 투자비중을 할당함으로써 많은 손실을 초래할 수 있기 때문에 $\mathrm{VaR}$ 의 한계를 완화하기 위해 Expected Shortfall을 채택하였다.

저금리 시대에 펀드 안정성에 대한 규제 등으로 부채연계 자산관리(liability-driven asset management)가 세계적으로 각광받고 있다. Sharpe and Tint(1990)는 포트폴리오 잉여금 제어를 위해 자산과 부채를 함께 고려하였으며, 구체적으로 부채 대 자산 비율을 이용한 평균-분산 모형을 채택하였다. Detemple and Rindisbacher(2008)는 Sharpe and Tint(1990)의 정적인 평균-분산 모형을 동적 모형으로 확장시켰는데, 자산과 부채 모두 확률 프로세스를 따르며 효용 함수는 Constant Relative Risk Aversion(CRRA) 형태를 따른다고 가정하였다. 그들은 자산과 부채를 함께 고려하는 적립비율 개념을 제안하였으며, 이를 투자 만기 때의 Expected Shortfall 조건으로 사용하였다. Ang et al.(2013)에서는 하락 위험(downside risk)을 제어하는 부채 중심의 투자 문제를 설계한다. 그들은 제약조건을 효용 함수에 적용한 평균-분산 문제를 유럽형 풋 옵션(European put option) 형태로 해석하여 풀어내지만, 포트폴리오의 동적 연관성을 고려하여 문제를 해결하지 못했다는 점에서 한계가 있다. 따라서 우리 논문은 포트폴리오 투자비율을 펀드매니저가 결정하며, 해당 펀드매니저가 포토폴리오 제약조건과 동적 계획을 모두 고려하는 문제를 풀고자 한다.

국내 연기금의 위험자산에 대한 투자비중 확대 필요성이 제기되고 있는 데에 반해 아직까지 연기금과 ALM을 함께 고려하는 연구는 부족한 편이다. Won(2009)은 향후 25년의 부채와 자산 프로세스를 예측하였고, 이를 활용하여 적립비율과 목표 수익률을 계산함으로써 자산과 부채의 배분 수준을 도출한다. 하지만 본 연구에서는 가정한 적립비율이 최대화되도록 동적 계획법을 활용하여 여러 개의 자산의 배분 수준을 결정한다. Lee and Sung(2008)는 자산과 부채 수익률의 차인 잉여금수익률을 극대화하는 문제를 제안하였으며, 여러 자산을 고려한다. 하지만 그들은 정적인 문제를 푼 것에 반해, 우리 연구에서는 동적으로 문제를 풂으로써 매 시점 최적의 투자비중을 알아낼 수 있다.

본 연구에서는 Kraft and Steffensen(2013)의 연구 방법론을 채택하지만 적립비율을 목적 함수로 사용한다. 부채 프로세스를 시간에 따라 변하는 프로세스로 일반화하여 최적의 위험 포트폴리오를 선택하고 가치 함수를 계산한다. 구체적인 예시로 부채가 지수 함수를 따라 증가한다고 가정한 모형에 대해서 탐구할 것이며, 이러한 가정 하에서 위험회피계수(coefficient of relative risk aversion)와 부채에 들어가는 모수가 최적 포트폴리오 구성에 미치는 효과를 조사한다.

이전까지 연구에서는 여러 개의 위험자산이 존재한다는 가정 하에 만기 $\mathrm{VaR}$ 제약조건을 고려하여 적립비율을 목적 함수로 하는 모형이 없었다는 점에서 본 연구가 방법론적으로 기여하는 바가 있다. 또한, 적절한 모수 설정을 통해 부채에 들어가는 모수, 위험회피계수, 그리고 자산 
한국증권학회지 제 50 권 1호 (2021)

간의 상관관계에 따른 적립비율의 변화를 알아내며 상황별로 연기금이 투자 전략을 어떻게 다르게 해야 하는지 수치적 함의를 도출함으로써 본 연구의 정책적 기여도가 크다고 할 수 있다. 본 연구는 위험회피계수의 존재로 투자자는 손실에 더 민감하기 때문에 적립비율이 낮을수록 위험자산에 대한 적극적인 투자를 확대하라고 제언한다. 또한, 미래에 예상되는 부채가 클수록 위험자산의 투자비중을 높이는 것의 이론적 당위성을 제공한다.

본 연구의 구성은 다음과 같다. 제 2 장에서는 본 논문의 연기금 적립비율 최대화 모형과 그에 따른 최적 자산 배분에 대해 살펴본다. 이때, 부채가 시간에 따른 프로세스일 때와 지수 함수를 따르는 프로세스일 때 모두에 대해 분석한다. 제 3장에서는 적절한 모수들을 이용하여 연기금이 각기 다른 상황 아래에서 투자 정책을 어떻게 세워야 하는 지에 대한 결과 분석을 제시한다. 제 4장에서는 결론을 맺는다.

\section{2. 모형}

본 연구에서는 펀드매니저가 무위험자산(예: $\mathrm{MMF}$ )과 위험자산(예: 주식, 장기채권)과 같은 두 가지 유형의 자산에 투자할 수 있다고 가정한다. 이때 위험자산은 $n$ 개 $(n \geq 1)$ 의 주식으로 이루어져 있고, 기하 브라운 운동(geometric Brownian motion)을 따른다고 가정한다. $B_{t}$ 가 시간 $t$ 일 때의 무위험자산의 가격이고 $S_{i, t}$ 가 각 위험자산의 가격이라고 할 때, 각 자산 가격의 시간에 따른 전개식(evolution equations)은 다음과 같다:

$$
\begin{gathered}
\frac{d S_{i, t}}{S_{i, t}}=\mu_{i} d t+\sigma_{i} d W_{i, t}, \quad S_{i, 0}=s_{i, 0}, \\
\frac{d B_{t}}{B_{t}}=r d t, \quad B(0)=1 .
\end{gathered}
$$

이때, $\mu_{\mathrm{i}}$ 는 각 위험자산의 기대수익률(expected rate of return), $\sigma_{\mathrm{i}}$ 는 각 위험자산의 변동성 (volatility)을 나타내며, $r$ 은 무위험자산의 수익률이다. $W_{i, t}$ 는 각 위험자산의 임의성(randomness)를 나타내는 표준 브라운 운동(standard Brownian motion)을 의미하며, 위험자산 간의 브라운 운동은

$$
\operatorname{Cov}\left(d W_{i, t}, d W_{j, t}\right)=\left\{\begin{array}{l}
\rho_{i, j} d t, i \neq j \\
d t \quad, i=j
\end{array}\right.
$$

와 같은 공분산을 갖는다. 따라서 무위험자산과 위험자산으로 이루어진 연기금의 총자산 프로세스는 아래와 같이 정의할 수 있다.

$$
\frac{d A_{t}}{A_{t}}=r d t+\sum_{j=1}^{n} \pi_{j, t}\left(\mu_{j}-r\right) d t+\sum_{j=1}^{n} \pi_{j, t} \sigma_{j} d W_{j, t}, A(0)=a_{0}
$$

이때, $\pi_{i, t}$ 는 시간 $\mathrm{t}$ 일 때 위험자산 $i$ 에 대한 투자비중을 말한다. 부채 프로세스는 아래와 
같이 임의의 시간에 대한 적분가능한 함수 $f(t)$ 를 도입하여 확률과정을 따르는 것은 아니지만 시변하게 정의할 수 있다1):

$$
d L_{t}=f(t) d t, L(0)=l_{0} \geq 0, l_{0}+\int_{0}^{t} f(s) d s>0
$$

본 연구에서 다루는 자산배분 문제는 적립비율을 마지막 시점 혹은 만기에 최대화하는 것이다. 본 연구에서 다룰 펀드의 적립비율(funding ratio)은 아래와 같이 정의된다:

$$
F_{t}=\frac{A_{t}}{L_{t}}
$$

이러한 적립비율의 정의에 의해 적립비율의 프로세스는 다음과 같이 표현할 수 있다:

$$
\frac{d F_{t}}{F_{t}}=\left(r+\sum_{j=1}^{n} \pi_{j, t}\left(\mu_{j}-r\right)-\frac{f(t)}{l_{0}+\int_{0}^{t} f(s) d s}\right) d t+\sum_{j=1}^{n} \pi_{j, t} \sigma_{j} d W_{j, t}, \quad F_{0}=f_{0} .
$$

따라서, 적립비율은 $\left(r+\sum_{j=1}^{n} \pi_{j, t}\left(\mu_{j}-r\right)\right)$ 의 비율로 단위 시간마다 증가하고, 부채가 증가하는 비율인 $\frac{f(t)}{l_{0}+\int_{0}^{t} f(s)}$ 의 비율만큼 단위 시간마다 감소한다.

이러한 셋팅 하에서 본 연구는 펀드매니저가 만기 시점인 $T \in(0, \infty)$ 에서 아래와 같은 Constant Relative Risk Aversion(CRRA) 형태의 효용 함수(utility function)를 최대화하도록 자산배분 문제를 설정한다. 즉 위험자산 투자비중을 조정하여 효용함수를 최대화 한 아래의 가치 함수 $V$ 를 구하는 것이 목적이다: 임의의 시간 $0 \leq t \leq T$ 와 $t$ 시점의 적립비율 $x$ (즉 $F_{t}$ ), 위험자산 투자비중 $\Pi_{t}=\left(\pi_{1, t}, \pi_{2, t}, \cdots, \pi_{n, t}\right)$ 에 대하여

$$
V(t, x)=\max _{\Pi_{t}} E_{t}\left[\frac{F_{T}^{1-\gamma}}{1-\gamma}\right], \quad \gamma>0, \gamma \neq 1
$$

이때, 상수 $0 \leq \alpha \leq 1$ 와 양의 상수 $\underline{F}$ 에 대하여 $\mathrm{VaR}$ 형태의 아래와 같은 제약조건

$$
P\left(F_{T}>\underline{F}\right) \geq 1-\alpha
$$

을 고려한다.2) 즉, 펀드매니저는 적립비율이 $\alpha$ 의 확률까지만 $\underline{F}$ 이하로 내려가는 것을 허용한다는

1) 이와 같은 모형은 연기금의 경우 미래의 부채를 현재 기준으로 추정해 낼 수 있다는 사실에서 그 의의를 갖는다.

2) 이와 같은 제약조건은 $\mathrm{VaR}=\underline{F}$ 인 경우라고 해석가능하나 연기금에서 흔히 다루는 숏폴 제약조건 (shortfall constraint)으로 해석할 수도 있다.

\section{8}


한국증권학회지 제 50 권 1호 (2021)

의미이다. 여기서 $\gamma$ 는 펀드매니저의 상대위험회피계수(coefficient of relative risk aversion)를 나타내며, $E_{t}$ 는 앞의 브라운 운동을 정의하는 실제 세계(real world)의 $P$ 측도 하에서의 $t$ 시점 조건부 기댓값(time- $t$ conditional expectation)을 의미한다. Grossman and Vila(1989), Grossman and Zhou(1996), Basak(1995)에서 볼 수 있듯이, 위 식 (7)의 관계식으로부터<부록 1>에서처럼 Hamilton-Jacobi-Bellman(이하 HJB) 방정식을 도출할 수 있다.

\section{1 일반적인 부채 모형에서의 최적 자산배분}

부록 1에서 최적해를 구하기 위한 1차 미분 조건(first-order condition; 이하 FOC)을 구하면 위험자산 최적 투자비중 $\Pi$ 를 $\mathrm{V}$ 에 대한 함수로 나타낼 수 있다: 각 $t$ 시점에서

$$
\Pi=-\frac{\Sigma^{-1}\left(M-r 1_{n}\right) V_{F}}{F V_{F F}} .
$$

여기서 $M=\left(\mu_{1}, \mu_{2}, \ldots, \mu_{n}\right)^{T}, 1_{n}$ 은 $n$ 크기의 1 로 이루어진 벡터, $V_{F}=\frac{\partial V}{\partial F}, V_{F F}=\frac{\partial^{2} V}{\partial F^{2}}$ 를 각각 의미한다. 또한 $\Sigma^{-1}$ 은 공분산 행렬의 역행렬을 의미한다. 그러나 $F_{t}$ 에 대한 제약조건을 고려하고 있기 때문에 직접적으로 $\mathrm{HJB}$ 방정식의 해를 구하기는 힘들다. 이러한 문제점을 해결하기 위해 몇몇 기존의 문헌(예: Kraft and Steffensen, 2013; Jang and Park, 2016)에서는 문제의 차원을 줄이고, 제약이 없는 자산 포트폴리오에 대한 옵션을 고려하는 방식으로 기존의 문제를 변형하여 제약식이 있는 경우의 해를 구한다.

본 연구에서는 Kraft and Steffensen(2013)의 방법론에 따라 벤치마크 포트폴리오 (benchmark portfolio) $X$ 를 구축함으로써 제약이 없는 문제와 제약이 있는 문제를 연계하는 방법을 도입한다.

벤치마크 포트폴리오의 프로세스는 Kraft and Steffensen(2013)의 방법론을 따를 때

$$
d X_{t}=\left(r+\frac{\theta \theta^{T}}{\gamma}-\frac{f(t)}{l_{0}+\int_{0}^{t} f(s) d s}\right) X_{t} d t+\frac{\theta}{\gamma} X_{t} d W_{t}, X(0)=x_{0}>0
$$

와 같이 표현된다.3) 이때, $\theta^{T}=\Gamma^{-1}\left(M-r 1_{n}\right)$ 으로 주식들의 표준편차로 이루어진 대각행렬 $\Gamma$ 의 역행렬과 주식들의 순 수익률의 행렬곱으로 이루어진 주식들의 샤프 비율(Sharpe ratio)을 의미하고, 시장에서 존재하는 여러 측도(measure) 중 하나를 골라 얻은 무위험 수익률(risk-free interest rate) $r$ 이 있다고 가정한다. $\Gamma$ 을 도입함으로써, 흔히 자산이 한 개일 때의 샤프 비율로 알려져 있는 $\frac{\mu-r}{\sigma}$ 를 표현하고자 한다. 즉, 벡터 $\theta$ 의 $i$ 번째 요소는 $\frac{\mu_{i}-r}{\sigma_{i}}$ 인 것이다. $U$ 를 벤치마크 포트폴리오 $X$ 에 대한 제약조건이 없는 적립비율의 현재 가치이자 $\mathrm{HJB}$ 방정식에 대한 해답 (solution)이라고 하면, $U$ 는 다음과 같이 나타낼 수 있다:

3) $F_{t}$ 와 $X_{t}$ 의 관계는 <부록 $2>$ 를 참고하기 바란다. 


$$
U(t, x)=E_{t, x}^{Q}\left[e^{-r(T-t)} g\left(X_{T}\right)\right] .
$$

여기서 $g$ 함수는 행사 시점의 가치에 대한 함수(claim function)이다.

결국 위험중립(risk-neutral)측도 $Q$ 가 있다고 할 때, 벤치마크 포트폴리오 $X$ 는

$$
d X_{t}=r X_{t} d t+\frac{\theta}{\gamma} X_{t} \widetilde{d W}_{t}
$$

로 표현될 수 있다.4)

한편 식 (11)의 우변의 식을 옵션의 $t$ 시점의 현재가치라고 해석한다면 $U$ 는 아래와 같은 Black-Scholes 편미분방정식(이하 PDE)을 만족해야 함을 알 수 있다:

$$
U_{t} d t=r U-r x U_{x}-\frac{1}{2} \frac{\theta \theta^{T}}{\gamma^{2}} x^{2} U_{x x}, \quad U(T, x)=g(x), U\left(0, x_{0}\right)=f_{0} .
$$

현재 시점의 적립비율인 $x$ 에 대한 함수인 $V$ 대신 제약조건이 없는 벤치마크 포트폴리오 $X$ 에 대한 목적 함수를 $\Psi$ 라고 하면 다음과 같이 표현할 수 있다:

$$
\Psi(t, x)=E_{t, x}\left[\tilde{u}\left(g\left(X_{T}\right)\right)\right]
$$

여기서,

$$
\tilde{u}(x)=\frac{x^{1-\gamma}}{1-\gamma}-\lambda_{\alpha} I_{(x<\underline{F})}
$$

이며 $I$ 는 지시 함수(indicator function)를 나타내며, $\lambda_{\alpha}$ 는 $\alpha$ 의 신뢰도를 가지는 라그랑주 승수(Lagrange multiplier)이다. 이제 $x$ 의 관점에서 옵션의 손익함수(payoff function) $g(x)$ 의 형태를 추측해야 한다. $\mathrm{VaR}$ 은 신뢰 수준과 관련있으므로 만약 이 신뢰 수준이 $100 \%$ 면 투자자가 하향 위험 또는 손실 위험에 대해 전체 금액이 보장이 되는 보험을 구입하여 포트폴리오를 보호해야 $\mathrm{VaR}$ 제약이 충족될 수 있다. 이는 최종 자산에 대한 풋 옵션을 매수함으로써 달성할 수 있다(두 번째 항). 만약 신뢰 수준이 100\%보다 작으면 극단적 손실과는 관련이 없는 것으로 간주된다. 따라서 투자자가 첫 번째 풋보다는 낮은 행사가로 다른 풋을 매도하게 된다(세 번째 항). 이를 반영하여 $g(x)$ 를 다음과 같이 정의한다:

$$
g(x)=x+(\underline{F}-x) I_{(x<\underline{F})}-\left(k_{\alpha}-x\right) I_{\left(x<k_{\alpha}\right)}-\left(\underline{F}-k_{\alpha}\right) I_{\left(x<k_{\alpha}\right.} .
$$

이때, $k_{\alpha}$ 는 상수이며 $P\{\mathrm{~g}(\mathrm{X}(\mathrm{T}))<\underline{\mathrm{F}}\}=\alpha$ 가 되는 $k_{\alpha}$ 값을 의미한다.5)

위험중립측도인 $Q$ 측도 하에 정의된 부 수준(wealth-level)의 벤치마크 포트폴리오 $X$ 를 그대로

4) $F_{t}$ 와 $X_{t}$ 의 관계는 <부록 2>를 참고하기 바란다.

5) $k_{\alpha}$ 을 구하는 방법은 <부록 $3>$ 을 참고하기 바란다. 
사용하면 유로피언 옵션 형태로 표현하는 데에 어려움이 있다. 이는 $X$ 의 변동성 부분인 $\frac{\theta}{\gamma}$ 이 벡터 형태로 이루어져 있기 때문인데, 변동성 벡터와 브라운 모형 벡터를 계산하면 브라운 모형의 합의 형태로 나타나므로 이를 하나의 다른 브라운 모형으로 표현을 하기 위해 $\sigma_{Y}$ 와 $d Y_{t}$ 로 치환을 한다. $Y_{t}$ 를 표준 브라운 모형으로 정의하기 위해 상수 $\sigma_{Y}$ 를 곱해주어 브라운 모형의 합의 형태와 같은 값이 되도록 맞추며, 이들은 다음과 같이 정의한다6):

$$
\sum_{i=1}^{n} \frac{\theta_{i}}{\gamma} d \widetilde{W_{i, t}} \equiv \sigma_{Y} d Y_{t}
$$

이를 이용하여 우리는 식 (11)과 식 (14)의 정의에 따라 $U$ 와 $\Psi$ 를 다음과 같은 유로피언 풋옵션 형태의 조합으로 나타낼 수 있다7):

$$
\begin{gathered}
U(t, x)=x+\operatorname{Put}\left(t, x, r, \sigma_{Y}, \underline{F}\right)+\operatorname{Put}\left(t, x, r, \sigma_{Y}, k_{\alpha}\right)-\left(\underline{F}-k_{\alpha}\right) e^{-r(T-t)} P^{Q}\left(X(T)<k_{\alpha}\right) . \\
\Psi(t, x)=\frac{e^{\tilde{r}(t)(T-t)}}{1-\gamma}\left[x^{1-\gamma}+\operatorname{Put}\left(t, x^{1-\gamma}, \tilde{r}(t),(1-\gamma) \sigma_{Y}, \underline{F}^{1-\gamma}\right)+P u t\left(t, x^{1-\gamma}, \tilde{r}(t),(1-\gamma) \sigma_{Y}, k_{\alpha}^{1-\gamma}\right)\right] \\
-\frac{e^{\tilde{r}(t)(T-t)}}{1-\gamma}\left(\underline{F}^{1-\gamma}-k_{\alpha}^{1-\gamma}+(1-\gamma) \lambda_{\alpha}\right) e^{-\tilde{r}(t)(T-t)} P\left(X(T)<k_{\alpha}\right) .
\end{gathered}
$$

이때,

$$
\begin{aligned}
& P u t(t, x, r, \sigma, K)=N\left(-d_{2}(t, x, r, \sigma, K)\right) K e^{-r(T-t)}-N\left(d_{1}(t, x, r, \sigma, K)\right) x, \\
& d_{1}(t, x, r, \sigma, K)=\frac{1}{\sigma \sqrt{T-t}}\left[\ln \left(\frac{x}{K}\right)+\left(r+\frac{\sigma^{2}}{2}\right)(T-t)\right], \\
& d_{2}(t, x, r, \sigma, K)=d_{1}(t, x, r, \sigma, K)-\sigma \sqrt{(T-t)}
\end{aligned}
$$

를 의미하며, $N(\cdot)$ 은 표준 정규 분포(standard normal distribution)의 누적분포함수(cumulative distribution function)를 의미한다. 또한

$$
\tilde{r}(t)=(1-\gamma)\left(r-\frac{f(t)}{l_{0}+\int_{0}^{t} f(s) d s}+\frac{1}{2} \frac{\theta \theta^{T}}{\gamma}\right)
$$

이다.

최적화 문제를 단순화하기 위해서는 우선 $U$ 와 $\Psi$ 의 관계를 알아내야 하는데, Kraft and Steffensen(2013)의 방법론을 따르면 다음과 같은 최적의 포트폴리오 전략 $\Pi^{*}$ 를 도출할 수 있다(<부록 5> 참조):

$$
\Pi^{*}=\frac{\Sigma^{-1}\left(M-r 1_{n}\right) x U_{x}}{\gamma U}
$$

6) $\sigma_{Y}$ 와 $d Y_{t}$ 의 값과 특성은 <부록 $4>$ 를 참고하기 바란다.

7) 아래 관계식을 유도하는 방법은 <부록 $5>$ 을 참고하기 바란다. 


\section{2 지수 함수 형태의 부채 모형에서의 최적 자산배분}

$\mathrm{VaR}$ 제약조건이 적립비율 최대화 문제에 미치는 영향을 더 직관적으로 설명하기 위해 다음과 같이 부채 프로세스가 지수 함수 형태를 띠는 특별한 경우를 다룬다: 임의의 상수 $\beta$ 에 대하여 $f(t)=\beta L_{t}$ 로 설정하면

$$
d L_{t}=\beta L_{t} d t \Leftrightarrow L_{t}=l_{0} e^{\beta t}
$$

$\beta$ 는 음도 가능하며 양의 경우 부채가 꾸준히 증가하는 경향을, 음의 경우 감소하는 경향을 나타낸다. 우리는 이때 $l_{0}=0$ 으로 가정하고, 이 경우, 적립비율 프로세스는 2.1 단원에서의 일반적인 모형에서 $\frac{f(t)}{l_{0}+\int_{0}^{t} f(s) d s}$ 부분이 $\beta$ 로 치환되는 것을 쉽게 알 수 있다. 즉,

$$
\frac{d F_{t}}{F_{t}}=\left(r+\sum_{j=1}^{n} \pi_{j, t}\left(\mu_{j}-r\right)-\beta\right) d t+\sum_{j=1}^{n} \pi_{j, t} \sigma_{j} d W_{j, t}, F_{0}=f_{0}
$$

가 성립한다. 적립비율의 프로세스에 따르면 단위 시간인 $d t$ 동안 적립비율은 부채 프로세스의 모수인 $\beta$ 비율만큼 감소한다. 벤치마크 포트폴리오도 같은 방법으로 계산하면 다음과 같다:

$$
d X_{t}=\left(r+\frac{\theta \theta^{T}}{\gamma}-\beta\right) X_{t} d t+\frac{\theta}{\gamma} X_{t} d W_{t}, X(0)=x_{0}>0 .
$$

또한, 2.1 단원에서와 같이 $Q$ 측도 하에서 $X$ 는 아래와 같이 표현된다:

$$
d X_{t}=r X_{t} d t+\frac{\theta}{\gamma} X_{t} d \widetilde{W}_{t}
$$

$U(t, x)$ 와 $\Psi(t, x)$ 도 각각 식 (18), 식 (19)과 비슷한 형태를 가지며, 이때 $P$ 측도 하에서의 $X$ 프로세스가 다르며 $\tilde{r}(t)$ 도

$$
\tilde{r}(t)=(1-\gamma)\left(r-\beta+\frac{1}{2} \frac{\theta \theta^{T}}{\gamma}\right) \equiv \tilde{r}
$$

와 같이 상수값으로 대체된다.

\section{3. 수치적 함의}

\section{1 기본 모수 설정}

본 연구에서 필요한 기본 모수(default parameters)들을 우리는 다음과 같이 설정하였다: $r$ 은 $2 \%$ 로 설정하였고, 결과의 해석을 용이하게 하기 위해 위험자산을 두 개 $(n=2)$ 로 두었으며, 결과를 얻기 위한 각 자산의 수익률과 변동성은 각각 $\mu=(0.05,0.06)^{T}, \sigma=(0.18,0.15)^{T}$ 로 설정 
한국증권학회지 제 50 권 1 호 (2021)

하였고,8) 위험자산 1 과 위험자산 2 의 상관관계 계수는 0.3 으로 설정하였다. $\mathrm{KDI}$ 경제정보센터에 2020년 10월에 게재된 자료에 따르면 무위험이자율은 $1.57 \%$, 그리고 주식위험프리미엄은 약 4.76\% 4.89\%라고 밝혔다. 또한, S\&P500 데이터에 따르면 표준편차는 최근 10년간 $13.5 \%$, 최근 5 년은 $15.21 \%$, 그리고 최근 3년은 $18.73 \%$ 이다. 따라서 본 논문에서는 최근 무위험이자율, 주식위험프리미엄, 그리고 표준편차를 활용하여 두 자산의 수익률을 $5 \%, 6 \%$, 그리고 표준편차를 각각 $18 \%, 15 \%$ 로 설정하였다. 두 자산 중 수익률이 높은 자산의 표준편차를 낮게 설정하였는데, 이는 한쪽 자산을 더 좋게 설정함으로써 최적 투자 비중이 차이가 나도록 하였다. 이는 만약 두 자산의 수익률을 $5 \%, 6 \%$ 그리고 표준편차를 각각 $15 \%, 18 \%$ 로 설정하면 두 자산이 양의 상관관계를 가질 때 거의 비슷한 최적 투자 비중을 가지기 때문이다. 본 연구에서는 두 경우의 비교를 위해 최적 포트폴리오 비중 그래프를 함께 분석하였다. 통상 연기금은 1 년마다 전략적 자산배분을 하기 때문에 투자의 만기는 $T=1$ 로 두었다(Marston and Craven, 1998; Edmans, 2009). 또한, $\mathrm{VaR}$ 제약조건의 확률 $\alpha$ 를 30\%로 설정하였으며, Basak and Shapiro(2001)를 따라 벤치마크 포트폴리오 $X$ 의 초기 가치를 $x_{0}=1$ 로 선택하였다. 한편, 부채 증가율 $\beta$ 를 $5 \%$ 로 설정하였고, 상대위험회피계수 $\gamma$ 는 Maenhout(2004)를 따라 2로 설정하였다. 또한, 목표적립 비율을 $100 \%$ 로 설정하였다.

\section{2 시간의 변화와 최적 자산배분}

<그림 1>은 시간 $t$ 에 따라 적립비율이 현재 벤치마크 포트폴리오 가치인 $X$ 에 대해 어떻게

\section{〈그림 1〉시간에 따른 최적 자산배분}

벤치마크 포트폴리오 $X$ 에 따른 적립비율의 관계를 나타냈다. $t$ 를 $0,0.3,0.6$, 그리고 0.99 일 때 적립비율이 어떻게 변하는지 알아보았다. 모수는 목표 비율을 $100 \%$ 로, $r$ 은 $2 \%$, 각 자산의 수익률과 변동성은 각각 $\mu=(0.05,0.06)^{T}, \sigma=(0.18,0.15)^{T}$ 로 두었으며, 자산 간의 상관관계 계수는 0.3 으로, 투자 만기는 $T=1$ 로 두었고, $\mathrm{VaR}$ 제약조건의 확률 $\alpha$ 를 $30 \%$ 로, 벤치마크 포트폴리오 $X$ 의 초기 가치를 $x_{0}=1$, 부채 증가율 $\beta$ 를 $5 \%$ 로 설정하였고, 상대위험회피계수 $\gamma$ 는 2 로 설정하였다.

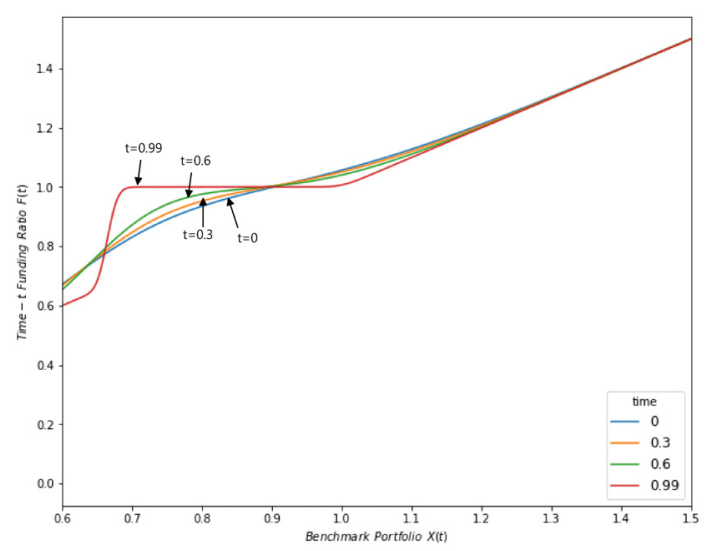

8) 따라서 기본 모수를 활용할 경우 위험자산 1 이 위험자산 2 보다 수익률과 변동성 두 관점 모두에서 더 열등한 자산이라는 사실을 알아야 한다. 
Optimal Asset Allocation of Pension Funds under a Value-at-Risk Constraint

변화하는지에 대한 그래프이다. 시간 $t$ 가 $0,0.3,0.6$ 정도일 때에는 적립비율이 벤치마크 포트폴리오에 대해 양의 관계를 가지는 것을 알 수 있다. 하지만 시간이 0.99일 때, 즉 거의 만기에 다다를수록 중간 영역에서 적립비율의 오목한 정도가 증가하며, 이는 $\mathrm{VaR}$ 제약조건이 있어 만기에 가까워질수록 펀드매니저가 미리 적립비율을 가능한 높이려고 하는 것이 최적 전략임을 나타낸다. 적립비율이 $100 \%$ 보다 작은 영역에서의 최적 자산배분 전략과는 다르게, 적립비율이 $100 \%$ 이상일 경우, 펀드매니저는 현재 충분한 부를 가지고 있으므로 열심히 적립비율을 높이려고 하지 않는 경향을 확인할 수 있다.

\section{3 두 위험자산 간의 상관계수와 최적 자산배분}

두 위험자산 간의 상관계수가 0.3 일 때의 적립비율에 대한 최적 포트폴리오 비중의 변화는 $<$ 그림 2(a)>와 같다. 위험자산 1 과 위험자산 2 의 그래프가 비슷한 개형을 갖고 있지만 위험자산 1 의 최적 포트폴리오 비중은 위험자산 2 보다 대부분의 경우 적다는 사실을 확인할 수 있다. 이는 위험자산 1 과 위험자산 2 가 양의 상관관계를 갖고 있지만, 위험자산 1 의 경우 위험자산 2 보다 수익률은 더 낮은 반면 변동성은 더 높기 때문에 위험자산 1 에 대한 투자가 적은 것으로 해석된다.

두 그래프 모두 적립비율이 $F(t)=k_{\alpha}$ 에서 최적 투자비중이 급격히 증가하는 모습을 관찰할 수 있는데, 이는 펀드매니저가 목표적립비율인 $100 \%$ 로 맞추기 위해 적극적으로 투자하는 것을 의미한다. 하지만, 적립비율이 $100 \%$ 에 가까워질 때, 두 위험자산 모두에 대해 그 비중을 급격히 낮춘다. 이는 투자비중을 높일수록 전체 포트폴리오의 변동성도 높아져 위험이 커지기 때문이다.

〈그림 2〉 $\mu=(0.05,0.06)^{T}, \sigma=(0.18,0.15)^{T}$ 인 두 자산 간의 상관관계 계수가 각각 $0.3,-0.3$, 0 일 때의 최적 자산배분

두 위험자산 간의 상관관계 계수가 각각 (a) 0.3 일 때의 적립비율에 대한 최적 포트폴리오 비중의 변화, (b) -0.3 일 때의 적립비율에 대한 최적 포트폴리오 비중의 변화, (c) 0 일 때의 적립비율에 대한 최적 포트폴리오 비중의 변화를 나타냈다. 두 위험자산 'asset1'과 'asset2'에 대해 적립비율에 대한 각각의 최적 포트폴리오 비중을 나타냈다. 모수는 목표 비율을 $100 \%$ 로, $r$ 은 $2 \%$, 각 자산의 수익률과 변동성은 각각 $\mu=(0.05,0.06)^{T}, \sigma=(0.18,0.15)^{T}$ 로 두었으며, 자산 간의 상관관계 계수는 0.3 으로, 투자 만기는 $T=1$ 로 두었고, $\mathrm{VaR}$ 제약조건의 확률 $\alpha$ 를 $30 \%$ 로, 벤치마크 포트폴리오 $X$ 의 초기 가치를 $x_{0}=1$, 부채 증가율 $\beta$ 를 $5 \%$ 로 설정하였고, 상대위험회피계수 $\gamma$ 는 2 로 설정하였다.

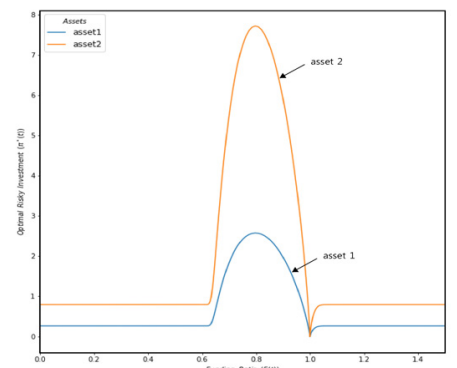

(a)

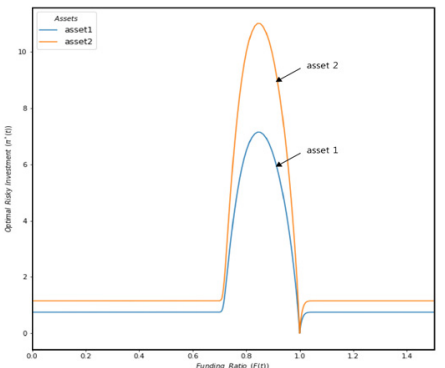

(b)

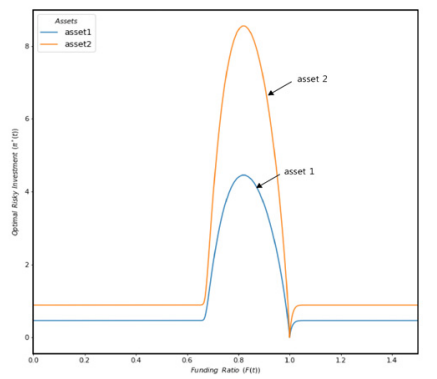

(c) 
한국증권학회지 제 50 권 1 호 (2021)

펀드매니저 입장에서는 적립비율을 $100 \%$ 에 맞추려고 하므로 위험을 감수하지 않고 단순히 위험자산에 대한 투자비중을 줄이게 된다.

두 위험자산 간의 상관관계 계수가 -0.3 일 때의 적립비율에 대한 최적 포트폴리오 비중의 변화는 <그림 2(b)>과 같다. 두 자산 모두 비슷한 개형을 갖고 있으며, 전반적으로 위험자산에의 투자비중이 상관관계 계수가 0.3 일 때보다 증가하였다. 이는 두 위험자산이 음의 상관관계를 갖고 있기 때문에 헷징 효과를 낼 수 있기 때문으로 풀이된다. 위험자산 2 에 대해서는 대부분의 적립비율 구간에서 $100 \%$ 이상의 투자비중을 보이며 펀드매니저가 적극적인 투자를 하는 것을 알 수 있다. 상관관계가 -0.3 일 때도 마찬가지로 펀드매니저는 적립비율이 $k_{\alpha}$ 인 영역 부근에서 위험자산에 대한 투자를 급격히 늘리고 $100 \%$ 에 가까워지면 급격하게 낮춘다.

두 자산이 독립일 때, 즉 상관관계가 0 일 때의 적립비율에 대한 최적 포트폴리오 비중의 변화는 <그림 2(c)>와 같다. 이 경우에도 앞선 두 그림과 비슷한 개형을 갖고 있다. 하지만 전체적인 위험자산 투자비중의 경우, 상관관계가 0.3 일 때보다는 증가하였지만 -0.3 일 때보다는 줄어들었음을 확인할 수 있다.

자산의 모수를 바꿨을 때의 변화를 알아보기 위해 수익률과 표준편차가 각각 $\mu=(0.05,0.06)^{T}$, $\sigma=(0.15,0.18)^{T}$ 인 두 자산의 그래프인 <그림 $3>$ 을 보면 두 자산의 최적 비중의 차이가 $\mu=(0.05,0.06)^{T}, \sigma=(0.18,0.15)^{T}$ 일 때보다 더 작은 것을 알 수 있다. 이는 어느 한 자산이 표준편차 대비 수익률이 확연히 뛰어나지 않기 때문이다. 하지만 전체적인 비중은 <그림 $3>$ 의 경우 훨씬 높아진 것을 알 수 있다. 이는 위험회피계수 $\gamma=2$ 일 때에는 투자자가 다소 위험하게 투자하는 것을 선호하기 때문에 변동성이 클 경우 미래에 높은 수익률을 기대하기 때문이라고 할 수

〈그림 3〉 $\mu=(0.05,0.06)^{T}, \sigma=(0.15,0.18)^{T}$ 인 두 두 자산 간의 상관관계 계수가 각각 0.3,

$-0.3,0$ 일 때의 최적 자산배분

두 위험자산 간의 상관관계 계수가 각각 (a) 0.3 일 때의 적립비율에 대한 최적 포트폴리오 비중의 변화, (b) -0.3 일 때의 적립비율에 대한 최적 포트폴리오 비중의 변화, (c) 0 일 때의 적립비율에 대한 최적 포트폴리오 비중의 변화를 나타냈다. 두 위험자산 'asset1'과 'asset2'에 대해 적립비율에 대한 각각의 최적 포트폴리오 비중을 나타냈다. 모수는 목표 비율을 $100 \%$ 로, $r$ 은 $2 \%$, 각 자산의 수익률과 변동성은 각각 $\mu=(0.05,0.06)^{T}, \sigma=(0.15,0.18)^{T}$ 로 두었으며, 자산 간의 상관관계 계수는 0.3 으로, 투자 만기는 $T=1$ 로 두었고, $\mathrm{VaR}$ 제약조건의 확률 $\alpha$ 를 $30 \%$ 로, 벤치마크 포트폴리오 $X$ 의 초기 가치를 $x_{0}=1$, 부채 증가율 $\beta$ 를 $5 \%$ 로 설정하였고, 상대위험회피계수 $\gamma$ 는 2 로 설정하였다.

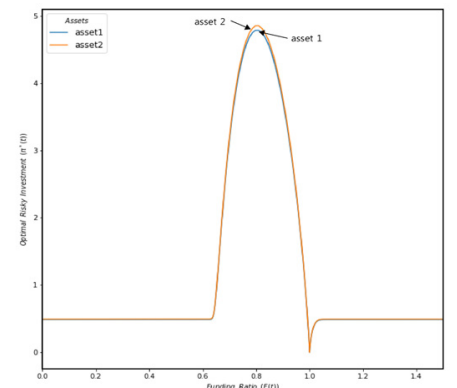

(a)

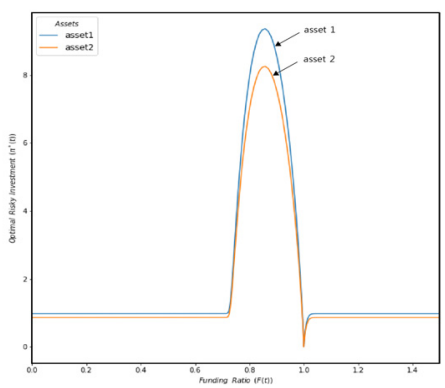

(b)

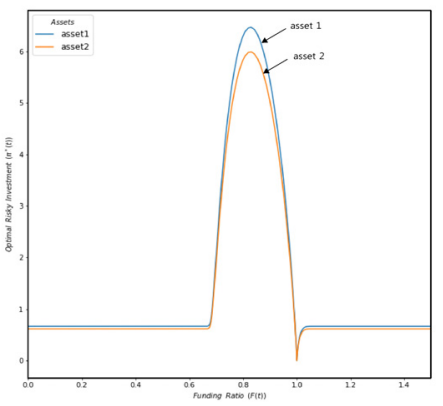

(c) 
Optimal Asset Allocation of Pension Funds under a Value-at-Risk Constraint

있다. 쉬운 비교를 위해 $\mu=(0.05,0.06)^{T}, \sigma=(0.15,0.18)^{T}$ 일 때 $\gamma=5$ 의 위험회피계수를 가지고 두 자산의 상관관계가 0.3 일 때의 그래프를 <그림 $5>$ 에서 찾아볼 수 있다.

\section{4 위험회피계수와 최적 자산배분}

<그림 4>에서는 $\mu=(0.05,0.06)^{T}, \sigma=(0.18,0.15)^{T}$ 인 두 자산에 대해 상대위험회피계수인 $\gamma$ 를 다르게 하며 두 가지 위험자산에 대해 모두 그 성향을 알아보았다. 두 자산 모두 위험회피계수가 클수록 적립비율이 $k_{\alpha}$ 보다 더욱 낮을 경우엔 더 낮은 비중을 투자하지만, 적립비율이 $k_{\alpha}$ 와 $100 \%$ 사이에선 계수가 클수록 더 많이 투자한다. 이는 위험을 기피하는 사람일수록 적립비율이 $100 \%$ 보다 조금 떨어졌을 때 $100 \%$ 에 맞추기 위해 위험자산에 대한 투자를 아끼지 않기 때문이다. 모든 경우에, $k_{\alpha}$ 부근에서 적극적으로 위험자산 투자비중을 늘리다가 $100 \%$ 에 가까워질수록 안정적으로 적립비율을 유지하기 위해 거의 모든 위험회피계수의 경우에서 투자비중을 급격하게 낮추는 것을 알 수 있다.

〈그림 4〉 $\mu=(0.05,0.06)^{T}, \sigma=(0.18,0.15)^{T}$ 인 두 자산의 위험회피계수에 따른 최적 자산배분 위험회피계수를 고려한 적립비율에 따른 최적 포트폴리오 비중 관계를 나타냈다. $\gamma$ 를 $1.5,2,5,7$, 그리고 10 으로 증가시키며 최적 포트폴리오 비중이 어떻게 변하는지 각각의 위험자산 'asset1'과 'asset2'에 대해 알아보았다. 모수는 목표 비율을 $100 \%$ 로, $r$ 은 $2 \%$, 각 자산의 수익률과 변동성은 각각 $\mu=(0.05,0.06)^{T}$, $\sigma=(0.18,0.15)^{T}$ 로 두었으며, 자산 간의 상관관계 계수는 0.3 으로, 투자 만기는 $T=1$ 로 두었고, $\mathrm{VaR}$ 제약조건의 확률 $\alpha$ 를 $30 \%$ 로, 벤치마크 포트폴리오 $X$ 의 초기 가치를 $x_{0}=1$, 부채 증가율 $\beta$ 를 $5 \%$ 로 설정하였다.
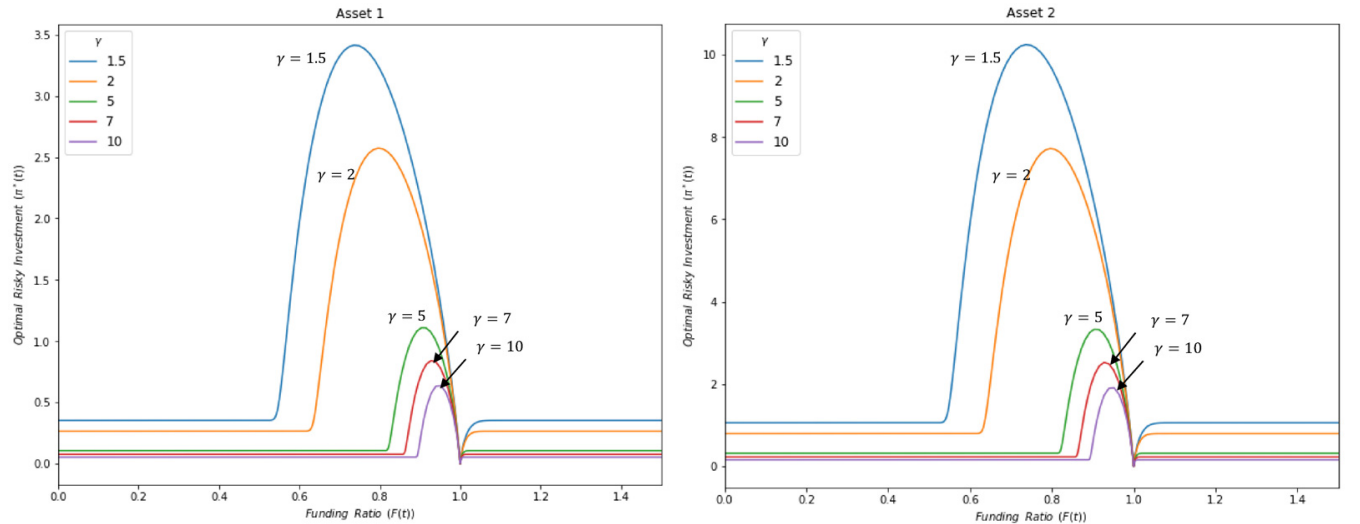

<그림 $4>$ 의 좌측은 위험회피계수의 변화에 따른 위험자산 1 의 최적 투자비중을 나타낸다. 위험자산 1 은 모든 위험회피계수의 경우에 적립비율이 $k_{\alpha}$ 이전까지 $40 \%$ 보다도 적은 투자비중을 유지하다가 적립비율이 $k_{\alpha}$ 와 $100 \%$ 사이일 경우에는 위험자산 2 보다는 상대적으로 적지만 갑자기 투자를 늘리는 전략을 택한다. 이는 위험자산 1이 상대적으로 수익률이 낮고 변동성이 높아서 그 영향이 크게 작용하였기 때문이다. 반면, <그림 $4>$ 의 우측은 위험자산 2 의 최적 투자비중으로, 위험자산 2 는 위험자산 1 에 비해 상대적으로 투자비중이 높아졌다. 적립비율이 $k_{\alpha}$ 이전의 위험회피계수에 따른 투자비중의 차이가 위험자산 1 에 비해 더 크게 나는 것을 알 수 있다. 
$<$ 그림 $5>$ 에서는 $\mu=(0.05,0.06)^{T}, \sigma=(0.15,0.18)^{T}$ 인 두 자산에 대해 상대위험회피계수인 $\gamma$ 를 다르게 하며 두 가지 위험자산에 대해 모두 그 성향을 알아보았다. <그림 $5>$ 의 좌측과 우측은 거의 비슷한 값과 개형을 보이는데 이는 $\mu=(0.05,0.06)^{T}, \sigma=(0.18,0.15)^{T}$ 의 경우와 다르게 위험자산 1 과 위험자산 2 중 어느 하나가 확실히 매력적인 상품이 없기 때문이다. <그림 $5>$ 의 경우에도 위험회피계수가 작을수록 더 많이 투자를 하며, 그 값이 커질수록 그 비중이 확연히 줄어드는 것을 알 수 있다.

〈그림 5〉 $\mu=(0.05,0.06)^{T}, \sigma=(0.15,0.18)^{T}$ 인 두 자산의 위험회피계수에 따른 최적 자산배분 위험회피계수를 고려한 적립비율에 따른 최적 포트폴리오 비중 관계를 나타냈다. $\gamma$ 를 $1.5,2,5,7$, 그리고 10 으로 증가시키며 최적 포트폴리오 비중이 어떻게 변하는지 각각의 위험자산 'asset1'과 'asset2'에 대해 알아보았다. 모수는 목표 비율을 $100 \%$ 로, $r$ 은 $2 \%$, 각 자산의 수익률과 변동성은 각각 $\mu=(0.05,0.06)^{T}$, $\sigma=(0.15,0.18)^{T}$ 인로 두었으며, 자산 간의 상관관계 계수는 0.3 으로, 투자 만기는 $T=1$ 로 두었고, $\mathrm{VaR}$ 제약조건의 확률 $\alpha$ 를 $30 \%$ 로, 벤치마크 포트폴리오 $X$ 의 초기 가치를 $x_{0}=1$, 부채 증가율 $\beta$ 를 $5 \%$ 로 설정하였다.
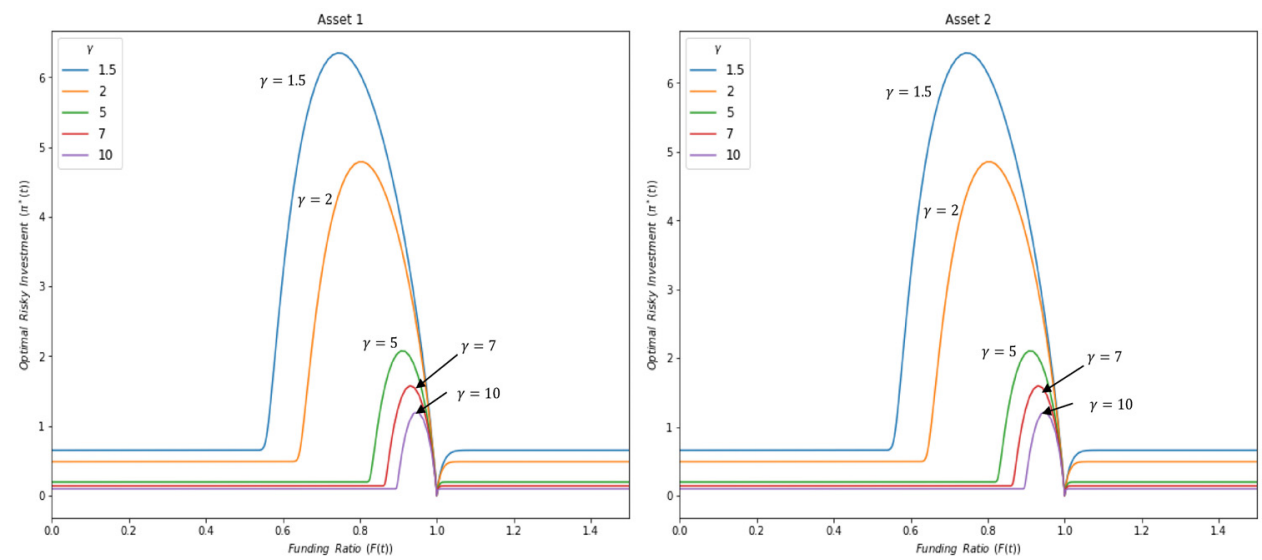

\section{5 부채증가계수와 최적 자산배분}

<그림 6>은 $\mu=(0.05,0.06)^{T}, \sigma=(0.18,0.15)^{T}$ 인 두 자산에 대해 부채 증가율 $\beta$ 에 따른 위험자산 1 과 위험자산 2 의 최적 투자비중을 나타낸다. 이 경우에도 위험자산 2 에 대한 투자비중이 위험자산 1 에 비해 확연히 높은 것을 볼 수 있다. $\beta$ 가 0 이상의 값을 갖는 경우, 즉 적립비율이 단위 시간마다 감소하는 방향일수록 적립비율이 상대적으로 더 낮은 구간에서 급격히 증가했다 감소하는 혹 모양(humped shape)이 나타나며, 그 최댓값 또한 더 높다. 이는 부채 혹은 지급액이 더 많을수록 더 적극적인 투자로 적립비율을 높이는 것이 필요하기 때문이다. 하지만 $\beta$ 가 0 이상인 구간에선 적립비율이 $100 \%$ 부근에서 펀드매니저는 최적 투자비중을 급격하게 줄인다. 이는 위험자산의 경우 변동성이 크기 때문에 적립비율이 $100 \%$ 밑으로 떨어지는 위험을 막기 위해서이다. $\beta$ 가 음수의 값을 갖는 경우, 단위 시간 동안의 적립비율이 증가하므로 $\beta$ 의 절댓값이 커질수록 더 적게 투자한다. 이는 부채 혹은 지급액에 대한 부담이 적기 때문에 펀드매니저가 적극적으로 투자하지 않아도 되기 때문이다. 양수인 $\beta$ 가 커질수록 최적 비중이 커지는 것은 
Optimal Asset Allocation of Pension Funds under a Value-at-Risk Constraint

펀드매니저가 $\mathrm{VaR}$ 제약을 고려해야 하기 때문에 포트폴리오의 손실에 더 민감하다는 사실과 관련이 있다.

〈그림 6〉 $\mu=(0.05,0.06)^{T}, \sigma=(0.18,0.15)^{T}$ 인 두 자산의 부채 증가 계수에 따른 최적 자산배분 부차 증가 계수를 고려한 적립비율에 따른 최적 포트폴리오 비중 관계를 나타냈다. $\beta$ 를 $-0.1,-0.05$, $0,0.05$, 그리고 0.1 으로 증가시키며 최적 포트폴리오 비중이 어떻게 변하는지 각각의 위험자산 'asset1'과 'asset2'에 대해 알아보았다. 모수는 목표 비율을 $100 \%$ 로, $r$ 은 $2 \%$, 각 자산의 수익률과 변동성은 각각 $\mu=(0.05,0.06)^{T}, \sigma=(0.18,0.15)^{T}$ 로 두었으며, 자산 간의 상관관계 계수는 0.3 으로, 투자 만기는 $T=1$ 로 두었고, $\mathrm{VaR}$ 제약조건의 확률 $\alpha$ 를 $30 \%$ 로, 벤치마크 포트폴리오 $X$ 의 초기 가치를 $x_{0}=1$, 상대위험회피계수 $\gamma$ 는 2 로 설정하였다.
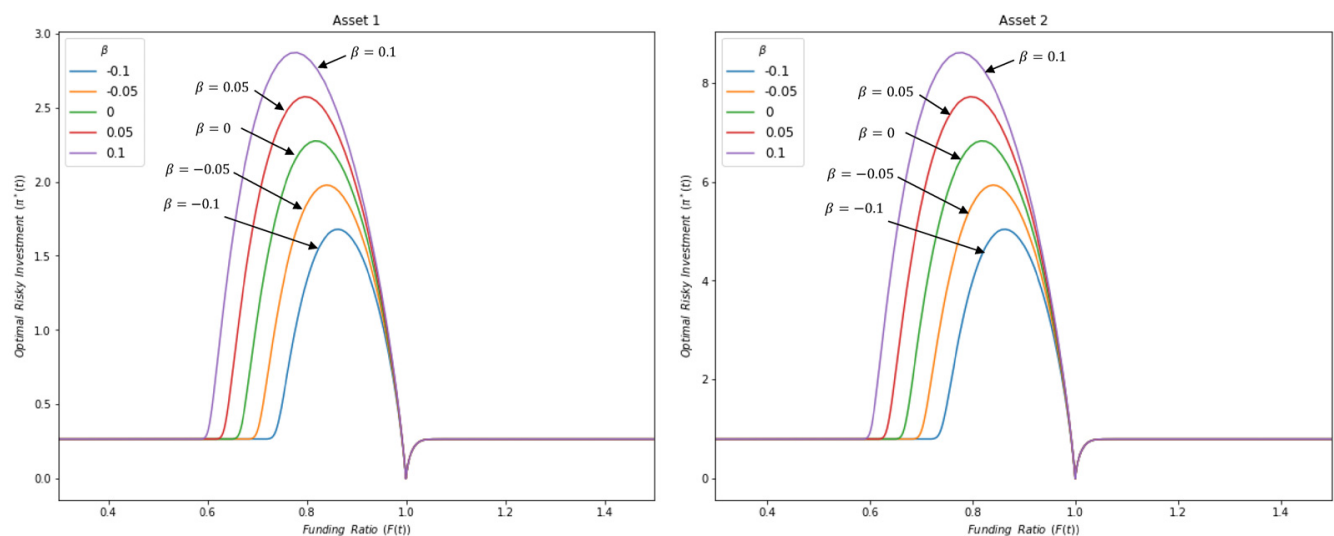

〈그림 7〉 $\mu=(0.05,0.06)^{T}, \sigma=(0.15,0.18)^{T}$ 인 두 자산의 부채 증가 계수에 따른 최적 자산배분 부차 증가 계수를 고려한 적립비율에 따른 최적 포트폴리오 비중 관계를 나타냈다. $\beta$ 를 $-0.1,-0.05$, $0,0.05$, 그리고 0.1 으로 증가시키며 최적 포트폴리오 비중이 어떻게 변하는지 각각의 위험자산 'asset1'과 'asset2'에 대해 알아보았다. 모수는 목표 비율을 $100 \%$ 로, $r$ 은 $2 \%$, 각 자산의 수익률과 변동성은 각각 $\mu=(0.05,0.06)^{T}, \sigma=(0.15,0.18)^{T}$ 로 두었으며, 자산 간의 상관관계 계수는 0.3 으로, 투자 만기는 $T=1$ 로 두었고, $\mathrm{VaR}$ 제약조건의 확률 $\alpha$ 를 $30 \%$ 로, 벤치마크 포트폴리오 $X$ 의 초기 가치를 $x_{0}=1$, 상대위험회피계수 $\gamma$ 는 2 로 설정하였다.
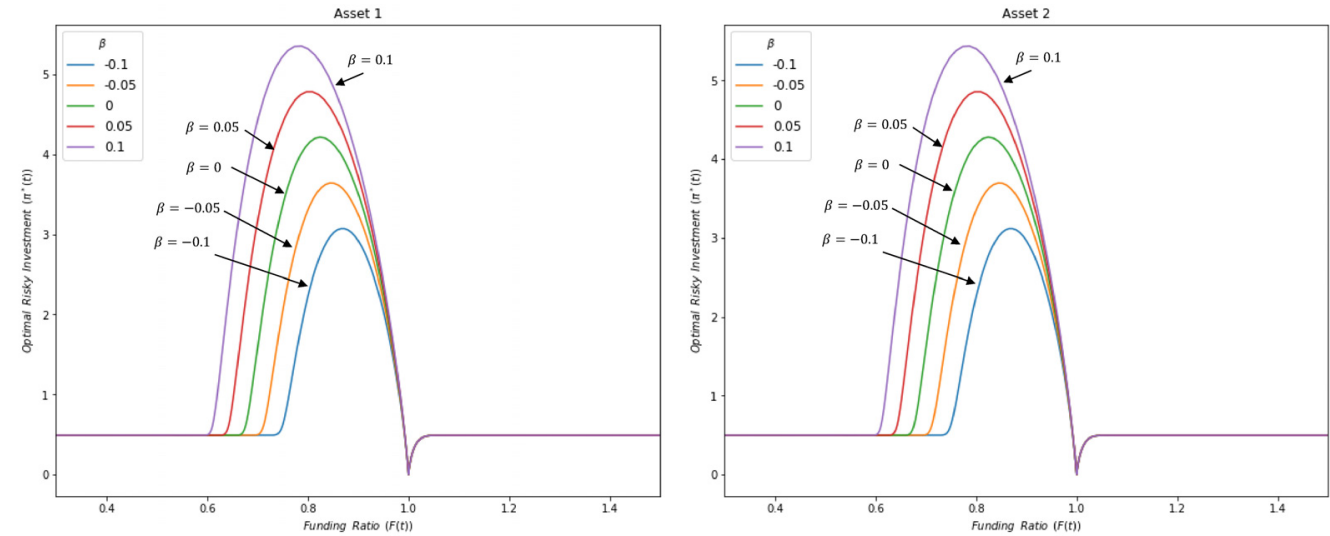
<그림 $7>$ 은 $\mu=(0.05,0.06)^{T}, \sigma=(0.15,0.18)^{T}$ 인 두 자산에 대해 부채 증가율 $\beta$ 에 따른 위험자산 1 과 위험자산 2 의 최적 투자비중을 나타낸다. 이 경우에는 위험자산 1 과 위험자산 2 의 최적 투자 비중이 비슷한 것을 알 수 있다. 또한 그 값은 첫 번째 경우인 $\mu=(0.05,0.06)^{T}, \sigma=(0.18,0.15)^{T}$ 에서의 위험자산 1 보다는 값이 크며 위험자산 2 보다는 각 $\beta$ 에 대해 작은 것을 알 수 있다.

\section{6 목표적립비율과 최적 자산배분}

<그림 8>은 $\mu=(0.05,0.06)^{T}, \sigma=(0.18,0.15)^{T}$ 의 수익률과 표준편차를 가지는 두 자산에 대해서 목표적립비율인 $\underline{F}$ 가 $80 \%$ 로 줄어들었을 때의 최적 투자비중을 나타낸다. 이때 모수들은 $\alpha=30 \%$ $\beta=5 \%, T=1, \gamma=2$ 로 동일하게 유지하였다. 이 경우, $\underline{F}$ 가 $100 \%$ 일 때와 유사한 모양으로 적립비율이 $F$ 부근에서 최적투자비중이 급격히 감소하는 것을 알 수 있다. 하지만 $\underline{F}$ 가 $100 \%$ 일 때인 <그림 2(a)>일 때보다 전체적으로 최적 투자비중의 값이 감소한다. 이는 목표적립비율이 상대적으로 낮아져서 $\underline{F}$ 가 $100 \%$ 일 때보다 위험자산에 덜 투자해도 되기 때문이다.

〈그림 8〉 $\mu=(0.05,0.06)^{T}, \sigma=(0.18,0.15)^{T}$ 인 두 자산에 대해 목표적립비율 $\underline{F}$ 의 영향 목표적립비율 $\underline{F}$ 를 80\%로 설정하였을 때의 두 위험자산 'asset1'과 'asset2'에 대해 적립비율에 대한 각각의 최적 포트폴리오 비중을 나타냈다. $r$ 은 $2 \%$, 각 자산의 수익률과 변동성은 각각 $\mu=(0.05,0.06)^{T}$, $\sigma=(0.18,0.15)^{T}$ 로 두었으며, 자산 간의 상관관계 계수는 0.3 으로, 투자 만기는 $T=1$ 로 두었고, $\mathrm{VaR}$ 제약조건의 확률 $\alpha$ 를 $30 \%$ 로, 벤치마크 포트폴리오 $X$ 의 초기 가치를 $x_{0}=1$, 부채 증가율 $\beta$ 를 $5 \%$ 로 설정하였고, 상대위험회피계수 $\gamma$ 는 2 로 설정하였다.

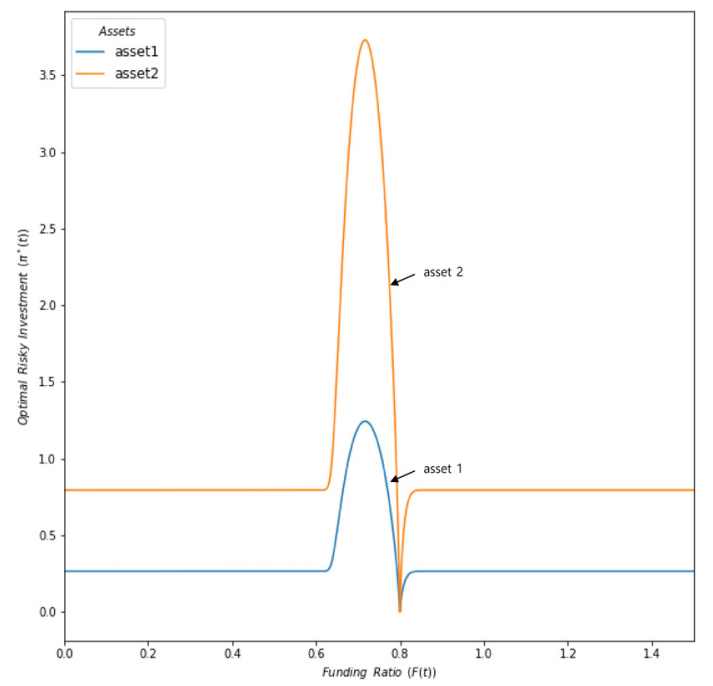

\section{7 실험 결과 종합}

이상을 종합해 보면, 연기금은 지급 만기가 가까워질수록 목표적립비율인 $100 \%$ 보다 현재 적립비율이 작을 때 적극적으로 투자하는 것이 최적 전략임을 알 수 있다. 또한, 위험을 회피하려는 정도가 클수록, 양의 부채 증가 비율이 클수록 적립비율이 목표적립비율인 $100 \%$ 보다 작을 
때 위험자산에 더 많은 투자를 해야 한다. 또한, 목표적립비율을 작게 설정하면 위험회피적인 펀드매니저 입장에서 위험자산에 덜 투자해도 되기 때문에 목표적립비율이 높을 때보다 최적 투자비중이 상대적으로 줄이게 된다.

연기금은 연기금 보유 주체의 투자성향을 파악하고, 미래의 지급액을 가입자와 수급자 증가 비율 등을 고려하여 추산한 후, 이를 바탕으로 목표적립비율 및 달성 확률을 설정하여 자금을 관리하여야 함은 자명하다. 본 연구는 투자기간 동안 목표적립비율에 도달하지 못할 손실에 대한 제약조건을 고려하여 초기 자산배분 전략 수립 단계에서 고려할 경우 기존의 투자전략과는 다른 투자전략이 현실적으로 최적일 수 있다는 사실에 대한 근거를 제공해 줄 수 있다.

\section{4. 결론}

본 연구는 연기금이 부채와 자산을 함께 고려한 자산부채종합관리 측면에서 여러 개의 위험자산과 적립비율, 만기에서의 $\mathrm{VaR}$ (혹은 솟폴) 제약조건을 고려하였을 때의 새로운 경제적 모형 및 최적 자산배분 방안을 제시하였다. 연기금은 통상 미래에 발생할 지급액을 추정한 것을 토대로 특정일자에 적립비율이 목표적립비율보다 높을 확률을 제약조건으로 고려하는 경우가 많아 본 연구에서는 연기금의 운용 실제에 사용 가능하도록 모형을 개발하였다. 또한 본 연구에서 사용한 모형은 기존의 연구에서 발전시켜 위험자산이 여러 개일 경우로 확장하였다. 본문의 예시에는 위험자산이 두 개일 경우를 들었지만, 비슷한 방법론을 사용할 경우 자산이 더 많을 경우도 연기금의 최적 투자 전략을 도출할 수 있다.

경제적 함의를 구하기 위해 적절한 모수를 선택하였으며, 예시를 통해 이러한 모형 하에서 투자자는 투자수익보다 투자손실에 더 민감하게 전략을 구사해야 한다는 사실을 알 수 있었다. 또한 이를 위해 적립비율이 목표적립비율보다 낮을 경우 적극적으로 위험자산에 투자해야 하는 경우도 존재하였다. 미래에 예상되는 지급액이 클수록 위험자산의 투자비중을 높이는 것이 중요하다는 사실도 발견하였는데, 이는 예상부채 혹은 미래 예상지급액의 증가가 단위시간 적립비율의 하락에 기여하기 때문이다. 위험자산 간의 상관관계도 투자비중에 큰 영향을 미치는데, 위험자산 간의 상관계수가 줄어들수록 위험자산의 전반적인 투자비중은 증가하나 위험자산 간의 투자비중 격차는 줄어드는 것을 확인하였다. 


\section{References}

Ang, A., B. Chen, and S. Sundaresan, 2013, Liability-driven Investment with Downside Risk, The Journal of Portfolio Management, Vol. 40, pp. 71-87.

Basak, S., 1995, A General Equilibrium Model of Portfolio Insurance, The Review of Financial Studies, Vol. 8, pp. 1059-1090.

Basak, S., and A. Shapiro, 2001, Value-at-risk-based Risk Management: Optimal Policies and Asset Prices, The Review of Financial Studies, Vol. 14, pp. 371-405.

Detemple, J., and M. Rindisbacher, 2008, Dynamic Asset Liability Management with Tolerance for Limited Shortfalls, Insurance: Mathematics and Economics, Vol. 43, pp. 281-294.

Edmans, A. 2009, Blockholder Trading, Market Efficiency, and Managerial Myopia, The Journal of Finance, Vol. 64, pp. 2481-2513.

Grossman, S. J., and J.-L. Vila, 1989, Portfolio Insurance in Complete Markets: A Note, Journal of Business, Vol. 62 (4), pp. 473-476.

Grossman, S. J., and Z. Zhou, 1996, Equilibrium Analysis of Portfolio Insurance, The Journal of Finance, Vol. 51, pp. 1379-1403.

Jang, B.-G., and S. Park, 2016, Ambiguity and Optimal Portfolio Choice with Value-at-Risk Constraint, Finance Research Letters, Vol. 18, pp. 158-176.

Karatzas, I., J. P. Lehoczky, and S. E. Shreve, 1987, Optimal Portfolio and Consumption Decisions for a "Small Investor" on a Finite Horizon, SIAM Journal on Control and Optimization, Vol. 25, pp. 1557-1586.

Kraft, H., and M. Steensen, 2013, A dynamic programming approach to constrained portfolios, European Journal of Operational Research, Vol. 229, pp. 453-461.

Lee, K., and J. Sung, 2008, Pension Fund Asset Allocation via Surplus Optimization Strategy, Korean Insurance Academic Society, Vol. 80, pp. 169-202.

Maenhout, P. J., 2004, Robust Portfolio Rules and Asset Pricing, Review of Financial Studies, Vol. 17, pp. 951-983.

Marston, C. L. and B. M. Craven, 1998, A Survey of Corporate Perceptions of Short-termism Among Analysts and Fund Managers, The European Journal of Finance, Vol. 4, pp. 233-256.

Sharpe, W. F. and L. G. Tint, 1990, Liabilities-a New Approach, Journal of Portfolio Management, Vol. 16, pp. 5-10.

Won, C., 2009, The Study of Investment Target with ALM Scheme in Nation Pension Fund, Korean Journal of Financial Studies, Vol. 38, pp. 27-51. 


\section{〈부록〉}

\section{〈부록 1〉 Hamilton-Jacobi Bellman 방정식}

동적 프로그래밍 접근법의 일반적인 방법론을 활용하면 $\mathrm{HJB}$ 방정식은 아래와 같이 표현할 수 있다:

$$
0=\max _{\Pi_{t}}\left[V_{t}+\left(r+\sum_{j=1}^{n} \pi_{j, t}\left(\mu_{j}-r\right)-\frac{f(t)}{l_{0}+\int_{0}^{t} f(s) d s}\right) F V_{F}+\frac{1}{2} V_{F F} \Pi_{t} \Sigma \Pi_{t}^{T} F^{2}\right] .
$$

이때, $\Sigma=\left[\sigma_{i, j}\right]$ 이며, 같은 제약식인 $P\left(F_{T}>\underline{F}\right) \geqq 1-\alpha$ 가 고려되어야 한다.

\section{〈부록 2〉 $F_{t}$ 와 $X_{t}$ 의 관계}

위험자산 최적 투자비중에는 가치함수의 $F_{t}$ 에 대한 편미분 값들이 포함되어 있다. 하지만 $F_{t}$ 는 $\mathrm{VaR}$ 제약이 있기 때문에 이를 풀기엔 어려움이 있다. 따라서 $F_{t}$ 를 제약이 없는 $X_{t}$ 프로세스로 변환하기 위해 최적 투자비중을 활용한다. 먼저 최적 투자비중은 다음과 같다:

$$
\Pi=-\frac{\Sigma^{-1}\left(M-r 1_{n}\right) V_{F}}{F V_{F F}} .
$$

이때, 제약이 없는 벤치마크 포트폴리오 $X_{t}$ 를 $F_{t}$ 대신 대입하고 상수 $K$ 에 대해 가치함수 $V$ 를 다음과 같이 정의한다:

$$
V=K \frac{F^{1-\gamma}}{1-\gamma}
$$

따라서 최적 투자비중은 다음과 같이 변형될 수 있다:

$$
\Pi^{*}=\frac{\Sigma^{-1}\left(M-r 1_{n}\right)}{\gamma} .
$$

이를 기존의 적립비율 프로세스에 대입한 후 벤치마크 포트폴리오로 표현하면

$$
d X_{t}=\left(r+\frac{\theta \theta^{T}}{\gamma}-\frac{f(t)}{l_{0}+\int_{0}^{t} f(s) d s}\right) X_{t} d t+\frac{\theta}{\gamma} X_{t} d W_{t}, X(0)=x_{0}>0
$$

와 같다. 또한, 위험중립(risk-neutral)측도 $Q$ 를 이용하여 드리프트(drift)값을 $r$ 로 표현하게 되면 벤치마크 포트폴리오 $X$ 는 아래와 같이 표현될 수 있다.

$$
d X_{t}=r X_{t} d t+\frac{\theta}{\gamma} X_{t} \widetilde{d W}_{t}
$$




\section{〈부록 3〉 $k_{\alpha}$ 유도식}

$g(x)$ 가 다음과 같은 값을 갖기 때문에

$$
g(X(T))= \begin{cases}X(T) & \text { if } X(T) \geq \underline{F} \\ \underline{F} & \text { if } k_{\alpha} \leq X(T) \leq \underline{F} \\ X(T) & \text { if } X(T) \leq k_{\alpha}\end{cases}
$$

$P[g(X(T))<\underline{F}]=\alpha \Leftrightarrow P\left[g(X(T))<k_{\alpha}\right]=\alpha$ 의 관계식을 갖는다. 또한, 이는 정규분포로 표현이 될 수 있다:

$$
P\left[g(X(T))<k_{\alpha}\right]=\int_{-\infty}^{n(x)} f(w) d w .
$$

이때,

$$
f(x)=\frac{1}{\sqrt{2 \pi T}} e^{-\frac{x^{2}}{2 T}}, n(x)=\frac{1}{\sigma_{x}} \ln \left(\frac{\mathrm{k}_{\alpha}}{\mathrm{x}_{0}}\right)-\left(\mu_{\mathrm{x}}-\frac{1}{2} \sigma_{\mathrm{x}}^{2}\right) \mathrm{T}, \sigma_{\mathrm{x}}=\frac{\theta}{\gamma}, \mu_{\mathrm{x}}=\mathrm{r}+\frac{\theta \theta^{\mathrm{T}}}{\gamma}-\frac{\mathrm{f}(\mathrm{t})}{\mathrm{l}_{0}+\int_{0}^{\mathrm{t}} \mathrm{f}(\mathrm{s}) \mathrm{ds}}
$$

의 값을 가진다.

〈부록 4〉 $\sigma_{Y}$ 와 $d Y_{t}$ 의 값과 특성

$$
\operatorname{Var}\left(\sum_{i=1}^{n} \frac{\theta_{i}}{\gamma} d \widetilde{W_{i, t}}\right)=\sum_{i=1}^{n} \frac{\theta_{i}^{2}}{\gamma^{2}} \sigma_{i}^{2} d t+\sum_{i, j, i \neq j}^{n} \frac{\theta_{i}}{\gamma} \frac{\theta_{j}}{\gamma} \sigma_{i} \sigma_{j} \rho_{i j} d t=d t\left(\sum_{i=1}^{n} \sigma_{i}^{2+} \sum_{i, j, i \neq j}^{n} \sigma_{i} \sigma_{j} \rho_{i j}\right) \equiv \sigma_{Y} d t .
$$

$\sigma_{Y}$ 를 위와 같이 정의하면

$$
\sum_{i=1}^{n} \frac{\theta_{i}}{\gamma} d \widetilde{W_{i, t}} \equiv \sigma_{Y} d Y_{t}
$$

로 브라운 모형의 합을 간단하게 표현할 수 있으며, 이때 $Y_{t} \sim N(0,1)$ 인 표준 브라운 모형을 나타낸다.

〈부록 5〉U(t,x)와 $\Psi(t, x)$

$$
\begin{aligned}
U(t, x)= & E_{t}^{Q}\left[e^{-r(T-t)}\left\{X(T)+(\underline{F}-X(T)) I_{\{X(T)<\underline{F}\}}-\left(\underline{F}-k_{\alpha}\right) I_{\left\{X(T)<k_{\alpha}\right\}}\right\}\right] \\
= & x+N\left(-d_{2}\left(t, x, r, \sigma_{Y}, \underline{F}\right)\right) \underline{F} e^{-r(T-t)}-N\left(-d_{1}\left(t, x, r, \sigma_{Y}, \underline{F}\right)\right) x \\
& -\left\{N\left(-d_{2}\left(t, x, r, \sigma_{Y}, k_{\alpha}\right)\right) k_{\alpha} e^{-r(T-t)}-N\left(-d_{1}\left(t, x, r, \sigma_{Y}, k_{\alpha}\right)\right) x\right\} \\
& -\left(\underline{F}-k_{\alpha}\right) e^{-r(T-t)} P^{Q}\left(X(t)<k_{\alpha}\right)
\end{aligned}
$$


Optimal Asset Allocation of Pension Funds under a Value-at-Risk Constraint

$$
=x+P u t\left(t, x, r, \sigma_{Y}, \underline{F}\right)+P u t\left(t, x, r, \sigma_{Y}, k_{\alpha}\right)-\left(\underline{F}-k_{\alpha}\right) e^{-r(T-t)} P^{Q}\left(X(T)<k_{\alpha}\right) .
$$

$$
\begin{aligned}
\Psi(t, x)= & E[\tilde{u}(g(X(T))] \\
= & \frac{e^{\tilde{r}(t)(T-t)}}{1-\gamma}\left[x^{1-\gamma}+N\left(-d_{2}\left(t, x^{1-\gamma}, \tilde{r}(t), \sigma_{Y}, \underline{F^{1-\gamma}}\right)\right) \underline{F^{1-\gamma}} e^{-\tilde{r}(t)(T-t)}\right. \\
& -N\left(-d_{1}\left(t, x^{1-\gamma}, \tilde{r}(t), \sigma_{Y}, \underline{F^{1-\gamma}}\right)\right) x^{1-\gamma} \\
& \left.-\left\{N\left(-d_{2}\left(t, x^{1-\gamma}, \tilde{r}(t), \sigma_{Y}, k_{\alpha}^{1-\gamma}\right)\right) k_{\alpha}^{1-\gamma} e^{-r(T-t)}-N\left(-d_{1}\left(t, x^{1-\gamma}, \tilde{r}(t), \sigma_{Y}, k_{\alpha}^{1-\gamma}\right)\right) x^{1-\gamma}\right\}\right] \\
& -\frac{e^{\tilde{r}(t)(T-t)}}{1-\gamma}\left(\underline{F^{1-\gamma}}-k_{\alpha}^{1-\gamma}+(1-\gamma) \lambda_{\alpha}\right) e^{-\tilde{r}(t)(T-t)} P\left(X(T)<k_{\alpha}\right)
\end{aligned}
$$

이 때 $\tilde{r}(t)=(1-\gamma)\left(r-\frac{f(t)}{l_{0}+\int_{0}^{t} f(s) d s}+\frac{1}{2} \frac{\theta \theta^{T}}{\gamma}\right)$ 이다.

또한, $U(t, x)$ 와 $\Psi(t, x)$ 는 다음과 같은 관계를 갖고 있다.

$$
\begin{aligned}
& \Psi(t, x)=e^{\tilde{r}(t)(T-t)} x^{-\gamma} U(t, x) \\
& \Psi_{x x}(t, x)=-\gamma e^{\tilde{r}(t)(T-t)} x^{-\gamma-1} U_{x}(t, x)+e^{\tilde{r}(t)(T-t)} x^{-\gamma} U_{x x}(t, x)=-\gamma x^{-1} \Psi_{x} .
\end{aligned}
$$

